\title{
Soft tissue mass of the calf as the presenting symptom of primary carcinoma of the lung
}

\author{
Bik Ling Man, ${ }^{1}$ Yat Pang Fu ${ }^{2}$
}

${ }^{1}$ Department of Medicine and Geriatrics, Tuen Mun Hospital, Hong Kong, Hong Kong ${ }^{2}$ Department of Medicine, Tuen Mun Hospital, Hong Kong, Hong Kong

\section{Correspondence to} Dr Bik Ling Man, beli_man@yahoo.com

Accepted 11 July 2015

\section{DESCRIPTION}

A 79-year-old man with a history of ischaemic stroke reported of progressive swelling and pain in the right calf for 1 month. He also had haemoptysis and weight loss for a few weeks. He denied any fever or poor appetite. Physical examination found a firm, tender mass over his calf (figure 1), left buttock and back. Positron emission tomography CT (PET-CT) scan showed a large, hypermetabolic necrotic mass at the right lung middle lobe with infiltration of the adjacent right upper and lower lobes (figure 2). Multiple hypermetabolic necrotic

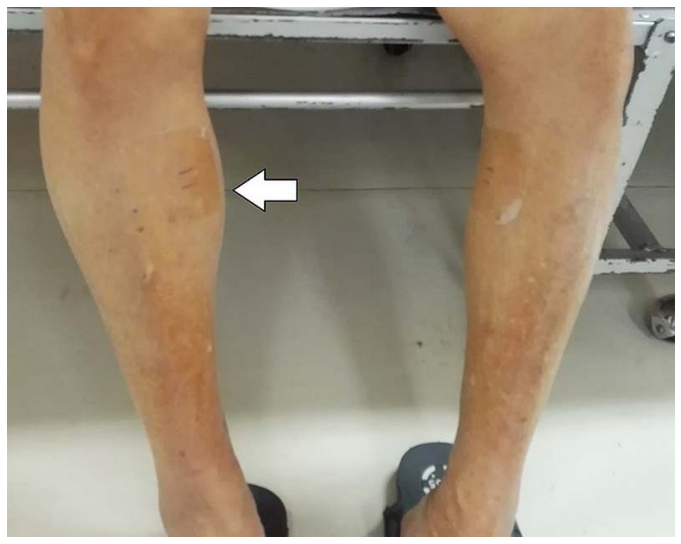

Figure 1 Soft tissue mass of the right calf (arrow).

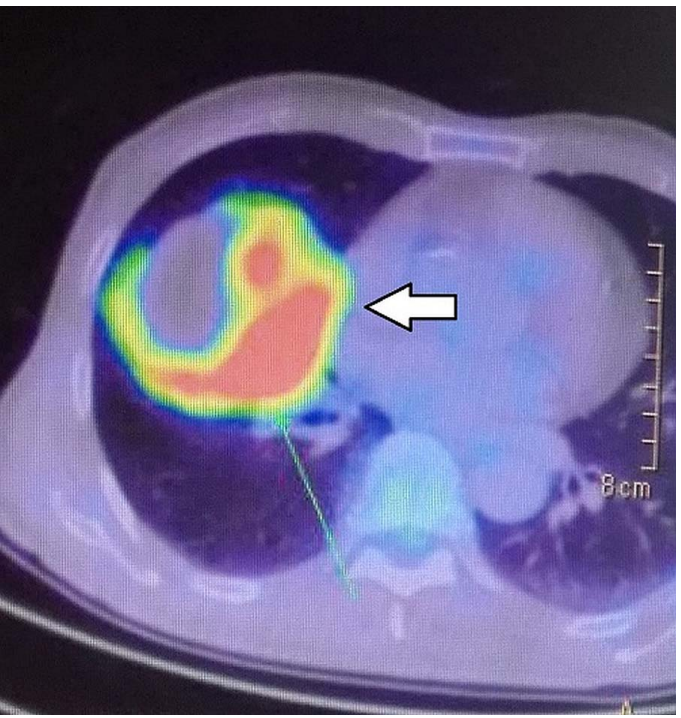

Figure 2 Positron emission tomography CT scan shows a hypermetabolic lesion located in the right lung middle lobe with infiltration of the adjacent right upper and lower lobes (arrow), measuring about $7.50 \times 7.37 \times 5.43 \mathrm{~cm}$. SUV max $=12.5$. SUV, standardised uptake values.

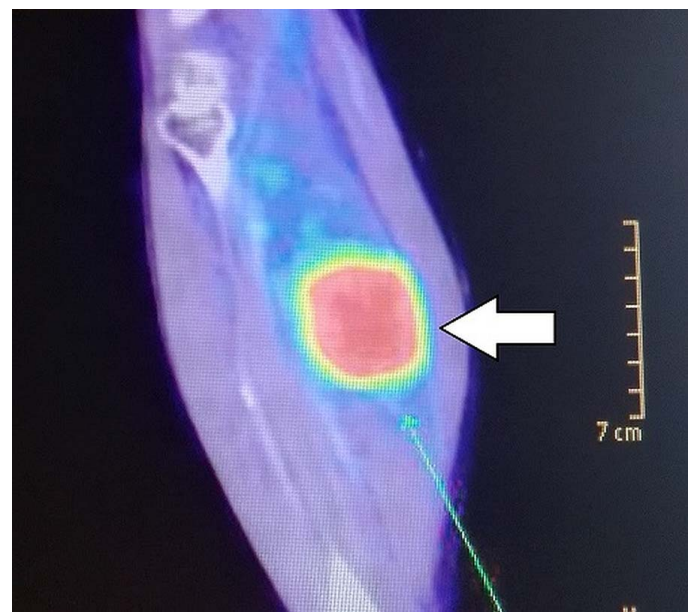

Figure 3 Positron emission tomography CT scan shows a hypermetabolic lesion located in the right calf (arrow), measuring about $4.04 \times 3.84 \times 3.96 \mathrm{~cm}$. SUV $\max =12.8$. SUV, standardised uptake values.

soft tissue masses were found in the right calf muscle (figure 3), posterior paraspinal muscles and bilateral thigh muscles (figure 4), which were suggestive of soft tissue metastases. Bronchoscopy and biopsy of the lung tumour revealed non-small cell carcinoma. Biopsy of the right calf mass showed metastatic non-small cell carcinoma. The histological features were similar to those of the lung tumour biopsy. The patient was referral to oncology for further management.

Soft tissue mass of the calf as the presenting symptom of primary carcinoma of the lung is rare.

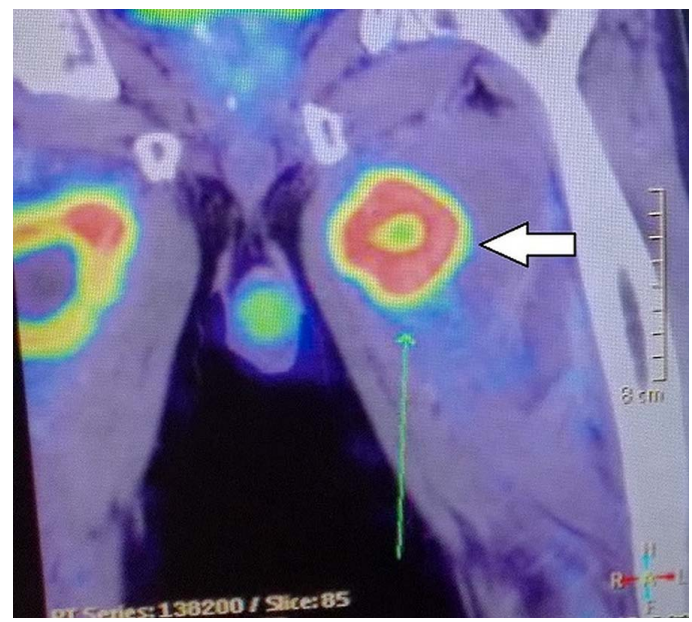

Figure 4 Positron emission tomography CT scan shows a hypermetabolic lesion located in the left thigh (arrow), measuring about $4.05 \times 3.50 \times 5.29 \mathrm{~cm}$. SUV $\max =12.2$. SUV, standardised uptake values. 


\section{Learning points}

- Soft tissue mass of the calf as the presenting symptom of primary carcinoma of the lung is rare.

- Common sites of metastases in primary carcinoma of the lung include the brain, adrenal gland, liver, abdominal lymph nodes, bone and kidney. Soft tissue metastasis is uncommon.

- Soft tissue metastasis is a sign of advanced disease and a grave prognostic factor.

Common sites of metastases in primary carcinoma of the lung include the brain (15-43\%), adrenal glands (18-38\%), liver (33-40\%), abdominal lymph nodes (29\%), bone (19-33\%) and kidney (16-23\%). Soft tissue metastasis is uncommon $(0.75-9 \%) .{ }^{1}$ It is a sign of advanced disease and a grave prognostic factor. ${ }^{2}$ PET-CT scan is very helpful in making prompt diagnosis.

Competing interests None declared.

Patient consent Obtained.

Provenance and peer review Not commissioned; externally peer reviewed.

\section{REFERENCES}

1 Perisano C, Spinelli MS, Graci C, et al. Soft tissue metastases in lung cancer: a review of the literature. Eur Rev Med Pharmacol Sci 2012;16:1908-14.

2 Baldeo C, Ali R, Seeram V, et al. Lung cancer presenting as a soft-tissue metastasis. Case Rep Oncol 2015;8:185-8.

Copyright 2015 BMJ Publishing Group. All rights reserved. For permission to reuse any of this content visit

http://group.bmj.com/group/rights-licensing/permissions.

BMJ Case Report Fellows may re-use this article for personal use and teaching without any further permission.

Become a Fellow of BMJ Case Reports today and you can:

- Submit as many cases as you like

- Enjoy fast sympathetic peer review and rapid publication of accepted articles

- Access all the published articles

- Re-use any of the published material for personal use and teaching without further permission

For information on Institutional Fellowships contact consortiasales@bmjgroup.com

Visit casereports.bmj.com for more articles like this and to become a Fellow 